\title{
The Influence of the Eastern Roman Civilization on the Imperial Portraits in Egypt and the Neighboring Countries from the First to the Fourth Century AD \\ Shaza Gamal Ismail \\ Faculty of Tourism and Hotel Management, Helwan University
}

\begin{abstract}
Roman Sculpture, with artists from across a huge empire and changing public tastes over centuries, is above all else, remarkable for its sheer variety and eclectic mix. The art form blended the idealized perfection of earlier Classical Greek sculpture with a greater aspiration for realism and absorbed artistic preferences and styles from the East to create images in stone and bronze which rank among the finest works from antiquity. Aside from their own unique contribution, Roman sculptors have also, with their popular copies of earlier Greek masterpieces, preserved for posterity invaluable works which would have otherwise been completely lost to world art. The aim of this paper is to discuss a distinguished type of Roman sculpture which is the portrait and the differences between the schools, periods, functions and characteristics in the eastern Roman Empire. Although the political circumstances around the empire was almost the same yet Egypt had always succeeded to keep its own style and special artistic features. Egyptian artists were always affected by their predecessors and tried to keep their culture and characteristics throughput the ages. The paper will try to move smoothly through these periods focusing on Roman Egypt and the art of portraits till the early period of Christianity.

Keywords: Imperial portraits, the Flavians, Trajan, mummy portraits, mixed Graeco Egyptian, schools of art, Philological division.
\end{abstract}

\section{Introduction}

Roman Art was perfectly described by Ron Van Der Meer referring to the remains of the glorious style of art even after the fall of the whole Roman Empire as follows: "The collapse of the Roman Empire left many of the great monuments of classicism in ruins. Yet as the Empire stumbled into the barbarism of the dark ages, classicism remained an ideal, synonymous with the glorious of the past". Roman sculpture did, however, begin to search for new avenues of artistic expression, moving away from their Etruscan and Greek roots, and, by the mid-1st century

$\mathrm{CE}$, Roman artists were seeking to capture and create optical effects of light and shade for greater realism. By later antiquity, there was even a move towards impressionism using tricks of light and abstract forms.

\section{Roman schools of art and Sculptors}

Roman art was influenced by several elements of other earlier styles of art. These were mainly the Etruscan, Greek, Hellenistic and Egyptian. This was applied to sculpture, painting as well as architecture. There were several attempts to identify the works of Roman art. These attempts can be classified as follows

\section{First: A philological division}

It is an attempt to classify the works of Roman art according to the name of a great master either on the basis of literary evidence or in much later date on affinities. An example of these works are the portraits of Caracalla and other members of the Severan dynasty whose sculptor was referred to as "Caracalla Master", and the portraits of Gordian II known as the "Gordian Master" 


\section{Second: The School division}

This is to divide each similar group of the works of art into schools. This method was applied to prevent the problem of unsigned masterpieces of art. As a result of this there were several attempts to study the characteristics of different media of art, for example, sculpture. Through comparing the similarities a convincing result might be deduced. Though this method helped to an extent in the classification of some of the works of art of the period, it still had its negative side.To understand the weak points of this method two types of schools should be mentioned:

\section{A-Typological Criterion}

This focused on workshops of local style, thus the location of the school was the main element of consideration.

\section{B-Stylistic Criterion}

Students from different parts of the Roman Empire worked under leadership of a certain artist. In this case the backgrounds of these students, their origin and method of work should be put into consideration. The best known sculptural workshops in the Roman Era were that from Aphrodisias. Its importance lies in the fact that it is considered the leading school of sculpture for the whole East and so forth to Alexandria. Some of their works of sculpture were carried on in Italy others in Asia Minor. The members of this school of art used to travel through the Empire working and thus had the chance to gain more money and fame by going to the people in their own countries rather than sending the products to them.

Although these two methods of division are the commonly used ones but still the problem of school remains unsolved. This difficulty might be attributed to two main reasons.

\section{First}

The international character of the period concerned with the same motifs, subjects, elements and functions. These were used all over the provinces of the Roman Empire

\section{Second}

The different interpretations of scholars and excavators of these monuments. This is due to the difficulties in studying Greek originals that were the base for most of the Roman copies besides the lack of information.

These two points might throw the light on some of the difficulties of a true, real classification of the works of art in general and sculpture in particular of the period. On the other hand the existence of local school of art can never be denied (Kleiner, 1992)

The Greek influence is to be considered one of the early stages of the development of the Roman style of art. This was not the case for the portraits, which were mostly of the Roman style of art. The Romans used to have death masks in stone copied in other materials such as terracotta or bronze with different sizes. During the history of the Roman Empire, sculpture passed through several stages affected mainly by the political changes through the reign of the emperors.

Roman sculpture can be classified into five main types:

\section{1-Imperial Portraits}

2-Relief Sculpture: Both of these kinds were used in public and private display

3-Idealising sculpture: These comprise the mythological figures, heroes, athletes as well as private statues for important citizens. Many of them were replicas of Greek or Hellenistic works of art. 
4-Decorative sculpture: These are various objects used in civic, religious or domestic purposes. Examples of these are the candelabra and table supports

5-The art of coinage: These are not to be considered among the categories of sculpture in itself but as mainly minor art. The link between it and sculpture lies in the ornamentation using the portraits of the Roman emperors.

\section{The Greek Royal Portraits in Egypt}

Before going into the details of the Roman portraits there should be a brief discussion concerning the Greek portraits as the first step of the development into the Roman ones. This discussion will be summarized in the form of certain points of differences between the Greek portraits and the Roman ones whether in function or style. This might help the reader to date the piece of art and to determine as well the Roman copies of Greek originals. In Egypt there are different kinds of portraits dating to both periods. Their main characteristics are the same as those applied to the whole eastern Hellenistic world through the Roman Empire, though there are some local features whether in style of sculpture or the subject of these portraits. These features are normally to be recognized as a result of the effect of the Ancient Egyptian art on the art of the Ptolemies, Hellenistic as well as the Roman. The royal portraits in Egypt during the Ptolemaic period can be classified according to their function, format and material. The main division is the purely pharaonic portraits, the Greek portraits and the mixed Graeco Egyptian portraits.

\section{First}

\section{The Pharaonic Portraits}

These carry the pharaonic elements, the features of kingship as represented in the art of the ancient Egyptians. They were made of hard Egyptian stones and in Pharaonic format. This is to be noticed from the back pillar supporting the statue, the statue with its static position represented either standing or seated wearing the lion cloth. There is a good account of these portraits in the Canopus and Rosetta decrees. Due to the choice of the material these portraits survived for a long period of time. There are several examples of this kind of sculpture in the round identified as pharaohs on the Ptolemaic period.

\section{Second}

\section{The Greek portraits}

These portraits are completely in Greek style with not much influence from the Egyptian style. The only thing that might not be recognized was the kind of stone that might have been brought from the Egyptian quarries. An example of this is to be found in the Boston museum of fine arts. It was bought in 1901 in Alexandria. It represents a bust of Ptolemy IV, Philopator in marble (222-204 BC) showing mostly Greek artistic features. The holes on both cheeks and under the chin indicate the separate attachment of the Greek style of the beard. The diadem at the back of the head reflects the Greek style of portrait sculpture of the period.

\section{Third}

\section{The mixed Graeco Egyptian portraits}

These are portraits with all the pharaonic regalia but with some facial features of Greek style, as well as the style of the hair which appears over the forehead recognized as Greek style. There are two examples of this kind, the first example is to be found in Alexandria museum abd make out of granite and was discovered at Canopus. The statue depicts Ptolemy VI Philomator (180-145 
BC) with Greek style face and hair. The second example is found in Brussels, Museé Royaux et d'art d'histoire. It is made out of black diorite but the place of discovery was not identified. It represents Ptolemy VIII, Eurgetes II (145-116 BC) I an Egyptian format with back pillar, double crowns, the ureaus and the Greek features (Smith, 1988)

From what is mentioned above it was very clear that the Ptolemies, who were Hellenistic kings in Alexandria, were patrons of the most artistic traditions. They were well aware of the differences between their artistic style of art and that of the Egyptians as well as the cultures. They tried to go through the mentality of the Egyptians through their works of art. This method was applied by employing Greek artists to perform the new works of art in Alexandria using some Egyptian local motifs. On the other hand, if they wanted to produce a certain piece of art which was intended to reach the Egyptians outside the Greek cities, they used Egyptian artists who mainly worked in the Pharaonic style of art in expressing the Greek subjects.

One of the best examples of this is the representation of the portraits of Queen Arsinoe II (316269 BC). This queen was represented twice, once in a Greek style and secondly in pure Egyptian style. The first one is now in Alexandria made out of marble. Her features are very similar to those depicted on her coins. It was designed in the traditional style of early Hellenistic sculpture, which reflects both the beauty of the face and the personality. The second one is found now in the Vatican Museum in Rome, made out of granite, it is a symbol rather than a portrait. The only way to recognize the character was the inscriptions on the pedestal. The Queen is represented in a full Egyptian style of art. She is standing with a left leg step forward, the Egyptian wig with three tresses two at the front and one at the back. Two uraei on the forehead, sometimes the same applied in ancient Egyptian statues one bearing the white crown of upper Egypt and the other one with the red crown of lower Egypt. (Pollitt, 1993)

\section{General differences between Greek and Roman of Imperial Portraits}

Through studying some examples of imperial portraits from Alexandria some characteristics can be deduced identifying major differences between Greek and Roman imperial portraits

First: The Greek portrait especially in earlier times represents the most prominent people. These were the poets, philosophers, historians, orators, generals and statesmen. Though this does not give a good chance for the representations of ordinary people, it still helps in facilitating the task of the identification of the different characters.

Second: The second main difference between the Greek portraits and those of later dates indicated that the Greek statues were not only portraits but they represent the whole body. The Greek artist wanted to show its capability in depicting the whole body, drapery and attitude. The Roman preferred to express all this through the facial features and in some cases bust statues.

Third: Greek portraits especially the earlier ones were not erected in private houses but in sanctuaries or tombs. These were applied for both types of portraits whether set up by the state or individuals to honor a friend or relative. It gradually developed to be erected in public places. The existence of some statues in public places such as the markets was exceptional especially in Athens. The idea of depicting a hero in Greek portraits was predominant. This was described by Pliny (XXXIV, 19, 74) on speaking of the statue of Perikles by Kresilas on the Akropolis, "it is a marvelous thing that in this art noble men were made to appear still nobler" Even in the realistic portrait of the Hellinistic in Egypt and elsewhere the idea still exists" (Richter, 1984)

\section{Roman Imperial Portraits}

After the Roman conquest of Greece in 146 BC, Greek artists settled in Rome. At the beginning they worked with their same style and sometimes they performed just imitations of the 
masterpieces they already have. There were two main reasons for the production of Roman copies.

\section{First}

\section{Availability}

A replica or copy cannot be produced unless the original statue is available. In some cases the monument intended to be copied could not be approached such as the famous chryselephantine statues which were displayed behind barriers. These statues could be observed only from a distance and a general idea was taken thus converted into a replica or copy.

\section{Second}

\section{Demand}

There is no point in an artist spending a lot of time, effort and money to make a statue, whether a copy or a replica, without being sure that he will get a lot out of that. This depends mainly on the subject matter of these works of art. Its importance to the Romans was the most considerable motive. These subjects were either historic or victorious statues. One of the greatest effects of Greek art was the life like portraits. The idea of portraits in general had played a great role in the early religion of the Romans. It became a custom to carry wax images of predecessors in funeral processions. Though it appears to be the same idea applied by the ancient Egyptian, the purpose in this case was completely different. As for the belief in ancient Egypt it was the more identical the features of the portrait the more easily the soul could recognize the deceased, thus, giving the chance to eternal life (Janson, 1965)

\section{Functions of Imperial Portraits}

When Rome became an Empire the portrait of the Emperor was still considered a religious symbol. Each Roman should present his loyalty to the Emperor by making offerings in the form of burning incense infront of the royal statue whether a portrait or a bust. This was the case for most of the Emperors such as Augustus, Nero or Titus. The persecutions of the Christians started by their refusal to make such kind of offerings. Another reason for propaganda, the Romans had the desire more than the Greeks to represent the portraits of the Emperor with his real features. The royal Roman portraits were applied for both public and private usage. The public ones acted as a sort of fame and propaganda to the Roman Emperor whether in the capital or in the provinces. These portraits were displayed according to their function. The public places for these portraits were mainly forum, basilicas and the crossroads of the city. A good example of this is the forum of Augustus. They were also placed in private places as the gardens whether in the modest houses or in the luxurious ones. In addition the Romans had museums or art galleries similar to the modern ones. The museum is a word of Greek origin and they had the same function as those found nowadays. In these art museums there was a good collection of the masterpieces of Roman art.

\section{Funerary Portraits}

In relief honouring freedmen presented in public places during Augustan times. Most of the Roman portraits were life size, others were carved in miniature. The colossal portraits were made for the emperor or one of the members of the ruling family. The original prototype of these portraits was manufactured in Rome. Marble copies were sent to the different provinces of the Empire such as Athens, Aphrodisias and Alexandria. These models were transferred as well to smaller provinces. Thus, the copies were sometimes not exactly the same as the originals. This 
created the difficulty of differentiating between replica and variants. Scholars define the replicas as the exact copies of the original portraits while the variants are those less likely to the originals and only resemble them in the general features not the details. Royal portraits were set up either alone, with images of gods or the emperor with his natural or chosen heir. In other cases the royal portrait was depicted with female members of the family or his predecessors (Kleiner, 1992)

\section{The Development of Roman Imperial Portraits}

Along the period of the Roman Empire, sculpture passed through the different stages affected mainly by the political changes through the reigns of the Emperors. The periods of Roman sculpture can be classified as follows:

\section{A-The Augustan Period (30 BC-14 AD)}

Augustus main plan on his ascension was the restoration of the republic and the creation of a new political style. His principal themes were religious, customs, virtues and the honour of Roman people. This resulted in several changes all over the Roman Empire. Part of these changes was in fact art with its different media and style. The portraits of this period were a mixture between the Greek style of art with its idealism and realism. It is the first step of development of portraits along the Roman history of art in general and of sculpture in particular. A good example of this period is the famous Augustus from Prima Porta. The style of art seems to appear in Rome about 20 BC. Since it was found in more than one hundred copies and replicas, it might have been a primary type of the portraits of Augustus. The statue is made out of two different kinds of marble. The head is of Greek marble while the body is of Italian marble. Comparing this statue with others for the same emperor suggests that this was sculptured at a late stage of his reign. This is due to the style of the toga, though the facial features indicate that he is still young. This might be taken as evidence that the statue was made by two artists besides the use of two kinds of stones. He is standing as if he is holding a Patera in his right hand ready to make offerings. From the style of his dress he is in the attitude of performing religious rite. Since this statue belongs to the early stage of Roman sculpture so it is still affected by the Greek style of art. The ideal features of the face and the style of the hair are typical of those of the fifth century BC athlete statues e.g. the Doryphoros of Poykleitos (Zanker, 1998)

\section{There are three main features to be mentioned about the portraits of Augustus}

First: He was the only Roman Emperor until the fourth century to be represented in all his portraits for a long period of time with the same age

Second: Most of his portraits were available to the locals and they were the first to be copied or duplicated in great numbers

Third: His portraits were the most reproduced, adapted and serviced for a long time in comparison to all other Emperors throughout the Roman Empire. (Smith, 1996)

\section{B-The Portraits from Tiberius to Flavians: 14-96 AD}

The portraits of this period were mainly bust statues for the emperors. This phase is a real development in the history of Roman royal portraits in both their elegance and their great concern showing some of the personal characteristics through the facial features. A great number of the portraits of Tiberius discovered in the Roman Amphitheatre in the Fayum, now exhibited in Copenhagen. In this portrait Tiberius is depicted in the mid-forties with his face turned to the left. This portrait was discovered among others of Augustus and Livia, which might be formed a 
dynastic group in the Amphitheatre. The style of the facial features indicates that imported sculptors made this portrait from Rome and not local ones. (Rutledge, 2002)

The portraits of the Flavian period had a new spirit, which differentiate between them and those of the Augustan period. Though the earlier ones were strict, rigid and bloodless, vitality life and directness marked the Flavian portraits. The representation of the loose hair and the nervous skin was the starting point of mastery of material, which had its influence on the whole development of royal portraits until the second century AD (Hekleir, 1912)

\section{C- The Reign of Trajan and Hadrian: 98-138 AD}

The portraits dating back to the reign of Trajan 98-117 AD can be classified into several types. The main difference between these types is the style of the hair over the forehead and on the neck. The first type dates back to the early years of his accession to the throne. An example of this type is to be found in the Museo Capitolino. He is represented shaven with a smooth face, which was one of the characteristics of his portraits. He is depicted here in a military attitude. Military themes were common both in the portraits of the Augustan and the Trajanic style of art. This is to be noticed in his example on the edge of the Plaudamentum on the left shoulder. The other type of his portraits are the Decennial type, which were made to celebrate the decennial of Trajan, the sacrifice type and the full length portraits (Kleiner, 1992)

As for the portraits of Hadrian (117-138 AD) there was a return to the idealism of the period of Augustus. He was well aware of the power of images, which explains the reason of the survival of many of his portraits. He preferred to be represented with his real features and it was suggested that he had curly hair since it was one of the main methods of distinguishing the Roman portraits. There is a portrait for him now in Capitoline Museum in Rome. In this portrait he is represented as the commander-in-chief of the emperor's far flung armies. The two figures on his shoulders were suggested to be a representation of Jupiter (Hannestad, 1994)

\section{D-From the time of Caracalla to the death of Constantine I: 211-337 AD}

As for Caracalla he was usually represented as a soldier with angry features. It seems that these were not his real features but it was the way he wished to be depicted. He thought that showing him like this gives him much resemblance to Alexander the Great on visiting Egypt with his family. He imitated the portraits of Alexander in the attitude of his head turned towards his left shoulder. It can be easily noticed that he was the first Roman Emperor to succeed in getting rid of the Hellenistic ruler diadem. This period was affected a lot by Eastern influences. Its features were the first step to the rise of the early Christian and Byzantine Art (Pollitt, 1993)

\section{Material used in Roman Sculpture}

Several materials were used in Roman sculpture. The type of material depends mainly on the function of the work of art as well as the status of the person to whom it will be dedicated. Other elements were considered such as the site in which the work was intended to be displayed, the availability of the material on the area and the craftsmen's skill. These materials varied between wood, which was used on the early period of the Roman Empire and rarely survived. Some metals such as bronze, silver and gold were used in a limited scale in comparison with top stones especially marble. There were two kinds of marble used in roman sculpture, these were white marble and coloured marble (Claridge, 1998) 


\section{White Marble}

It was the most commonly used. It was brought mainly from Greece, the Aegean Islands and the western coast of Turkey. It was not available in the west until the reign of the Roman Emperor Augustus in $27 \mathrm{BC}$. The emperors of the first century AD controlled completely the quarrying and transportation of the stone. The most famous kind of white marble at that time Luna marbles which was brought from the Apuan Alps in Italy. Caesar was the first to apply this kind of marble (Carrara) when he used it for the walls of his house. In the first century AD there were the different levels of workshops for this kind of marble in the western provinces which were:

First: Travelling workshops coming from Rome and Italy

Second: Provincial workshops influenced by the previous one

Third: Local Workshops (Pensabene, 1995)

There were other sources of white marble such as Parian marble from Mt Pentelikon in Greece, Dominican from Bacakale in west central Turkey, Thasian marble from the island of Thasos in the northern Agean and the island of Prokonneses in the sea Marmara

\section{Coloured Marble}

The Romans started quarrying different kinds of stones from the reign of the Roman Emperor Augustus and continued to the end of the fourth century AD. Different kinds of Egyptian stones were exported to the Roman Empire to areas like Italy, Ostia, Pompeii and Herculaneum and at the Villa of Hadrian in Tivoli. Outside Italy as well there is a good evidence for the activities of Roman quarrying in the land of Egypt. Some of these places are ancient Constantinople (modern Istanbul, Turkey), Ephesus. Antioch and Alexandria. They exported granite from Aswan and travertine (Egyptian alabaster) from several quarries between Assiut and Minya in Middle Egypt (Brown \& Harell, 1995). The most famous stone of this kind was red porphyry from the mountains of the eastern desert in Egypt.

There are nineteen known Roman quarries in the site (Perkins, 1992). Its imperial purple colour was suitable for the representations of certain statues as the statue of goddess Roma and the emperors wearing the toga. Some Emperors were depicted completely with this colour while others were buried in sarcophagi of this material. There are other less common kinds of coloured marble such as red marble from Cape Tainaron (Matapan, Greece) and Iasos (south west Turkey) in red wine colour that was used for statues of Bacchus, god of wine. Purple and white variegated Phrygian marble was quarried in central Turkey, which was used for mythological scenes. Besides coloured alabaster was used also by the Romans such as the yellow, brown and variegated alabaster. These most probably came from Syria, Egypt, Tunisia and Algeria (Claridge, 17-19)

\section{The Portraits of the Roman Emperors in the works of the Classical Writers}

All what was mentioned above were the ideas and thoughts of modern scholars. It is found necessary to have a look through some of the examples of the classical writers, the way they viewed the Roman Imperial portraits, its function and importance in the Empire. Some of these writers had the chance to see these monuments at the time of their erection, which will provide a great deal of the incidents taking place at that time. Besides, it will help in explaining various functions and reasons for such style of sculpture which will be really difficult to find out without referring to the works of those who were actually on the stage.

One of the descriptive definitions for portraits in general is that found in Ars Poetica 180-182 saying "What the mind takes in through the ears stimulate in less vigorously than those which are set before the eyes and which the spectator can see and believe for himself" The Roman portraits 
in general were a direct reflection at the political status and attitude of the inhabitants. Plutarch explained this in his biography of Flaminius. Plutarch suggested watching the statues of the great general by the circus in Rome. He saw that this statue shows his wild character "Both in anger and graciousness" (Plut. Flami.1) A more interesting comment was the one that he made on the bronze statue of Iunius Brutus, the tyrannicide, who was represented, with his sword "indicating how steadfast he was in overthrowing the Traquins" (Plut, Brut.1.1) (Gregory, 1996)

One of the main functions of the Roman portraits was the commemoration of the Emperors both for social and religious reasons. Dio Cassius discussed the erection of the statues of Julius Caesar to honour him.

Dio Cassius XLIII "the road (the Via Flaminia) was finished just at this time (27 BC), and for that reason statues to Augustus were made for the arches of the bridge over the Tiber and also at Ariminum (Rimini). The other roads were finished later, either at public expense (for none of the senators would willingly spend money on them) or at the expense of Augustus, whichever way one likes to describe it. For I am unable to find any distinction between the two treasuries, even if I allow for the fact that Augustus, had converted into coins silver statues of himself which had been offered by some of his friends and by certain subject people, in order to make it seem that everything he claimed to spend on the roads came from his private resources"

Tiberius 14 AD-37 AD During his reign there was a general lack of innovation in the works of sculptire. He was fond of and greatly affected by the Greek art just like Augustus.

Tacitus Annals IV, 9: “ The story that Tiberius removed the famous Apoxyomenos of Lysippos to his bedroom because he had fallen in love with it is no doubt scurrilously exaggerated but probably does reflect the fact that Tiberius, like Augustus, had a fondness for Greek art" $\mathrm{He}$ encouraged artists to erect statues honouring his predecessors specially Augustus. An example for this was the statue of Augustus exhibited at the funeral of his son Drusus in 23 AD. A great collection of Imperial portraits was presented in this funeral such as Aeneas, the founder of the Julian family, all the Alban kings, Romulus the founder of Roma, and after them the Sabine nobles, Attus Clasus, and portraits busts of all other Claudii in a long procession.

Dio Cassius LVIII, 12,5: "Very few words are known to have been set up on the initiative of Tiberius himself. After the conspiracy of Sejabus was thwarted, a figure of "liberity" was set up in the forum, an obsidian statue, which had apparently been plundered by Sejanus' father, was restored to its place in Egypt (Pliny, N.H.XXXVI, 197).

Caligula 37 AD-41 AD: According to Suetonius Caligula was very eager to erect as many statues for him as he can. On the other hand he wanted to surpass those of others.

Suetonius, Gauis Caligula XXXIV: "With no less envy and malignity than arrogance and ferocity he raged against the human race in almost every epoch. He overturned the statues of famous men, which had been moved by Augustus to the Campus Maritus from the Capitoline, where the space had been cramped, and he broke them into pieces to such an extent it has been possible to restore them with their inscriptions intact. In fact, he came very near to removing the writings and portraits of Vergil and Titus Livius from all the libraries, the former he used to crap at on the grounds that he had no inscriptions and minimal learning, the latter because he was verbose and careless in his history"

Claudius 41 AD-54 AD At the beginning of his political life he had some bad experience with portrait statue during the reign of Caligula

Suetonius, the divine Claudius IX, 1: “......... In his own consulship (AD 37) under Caligula he came very near to being removed from office because he had been rather slow about contracting for and setting up statues of Nero and Drusus (Gauis) Caesar's brothers. As a result 
he was much similar to Tiberius in the way that he was not very interesting in having statues or even busts portraits for himself

Dio Cassius LX, 5,4-5: “.........He forbade that anyone should worship him or sacrifice to him........At first he accepted only one portrait, and that merely of silver, and two statues one of bronze and one of stone, which were voted to him. Expenses of this sort, he said, were futile and, in addition to that, they provided the city only with great loss and annoyance. In fact, the public buildings were so filled with statues and votive that he said he would give some thought to the problem or what was to be done with them"

Nero 54 AD-68 AD The most famous sculptor of his age was Zenodoros who made for him the colossal, which stood in the vestibule of the Domus Aurea

Pliny, N.H.XXXIV, 45-47 "But it was in our age that all the other statues of this sort (colossal statues) were surpassed in size by the Mercury of Zenodoros, which was made in the city of Averni in Gaul, took ten years to complete, and cost forty million sesterces. After he had given sufficient proof of his artistic ability, Nero summoned him to Rome and there made that colossal image 120 feet in height. It was intended to be a representation of that emperor but which now, since the infamous acts of the emperor have been condemned, is dedicated and revered as an image of the sun". There was an opinion that Nero's attitude towards others' monuments was aggressive and destructive.

Suetonius, Nero XXIV “Concerning the emperor's activities in Greece while he was competing in the Olympic Games. And so that no memory or trace of any victor in the games.

Other than himself should remain. He ordered that all their statues and portraits should be overturned, dragged off with hooks, and thrown into latrines.

The Flavians 69 AD-96 AD, Vespasian 70 AD-79 AD He placed in the temple of Peace many of the famous works of Greek sculpture, which were removed or damaged by Nero. The most remarkable work in this temple was a large statue representing the River Nile made out of local Egyptian stone

Pliny N.H.XXXVI, 58 "Egypt is also the source of stone found in Ethiopia which they call basanites; it has the colour and hardness of iron, for which reason his name has been given to it. There has never been a larger specimen of it found than that from which the statue representing the Nile, dedicated by the Emperor Vespasian Augustus in the Temple of peace, was made; playing around the Nile were sixteen figures of children, through which are conveyed the total number of cubits which the river rises at its high flood point"

Domitian 81AD-96 AD A large statue was of Domitian was placed in the forum between the Basilica Aemilia and the Basilica Julia opposite the temple of the Divine Julius. This statue was described by the famous poem Statius as follows:

Statius, Silvae I, 1 "What is the massive form, doubled by the colossus surmounting it, which stands in and embrace the Latin (Roman) forum? Did the work fall in finished form from heaven? Was the statue shaped in Sicilian furnaces, and did it leave steropes and Brontes exhausted? Or did the hands of Pallas mode your statue for us. O Germanicus, holding the reins as you did when the Rhine and the steep home of the astonished Dacian saw you?"

Most of the statues were destroyed after his death, which make a difficulty for producing either replicas or copies

Procopius, Anecdota in his book (Secret History) VIII, 18-21 mentioned that the only statue left for Domitian in the whole Roman Empire was that made by his wife after his death. In order to provide the sculptor with a model for Domitian she had to reassemble the already

Broken statues and the different parts of it 


\section{The "Five Good Emperors" and Commodus 96 AD- 185 AD}

\section{Tajan 98 AD-117 AD}

The literary evidence for the architectural buildings and statues of Trajan is considered very limited in comparison to those of other Emperors. Pausanias gave the best description of one of his statues. This statue was found among others in the pronaos of the temple of Zeus at Olympia

Pausanias V, XII, 6: "There are also statues of Emperors, one of Hadrian in Parian marble set up by the cities which form the Achaen confederacy, and one of Trajan, set up by all the Greeks. This latter Emperor was victorious over the Getae who live north of Thrace and waged war against Osroes, the descendant of Arsaces, and the Parthains"

Hadrian 117 AD-137 AD There were statues for Hadrian all over the Roman Empire. In the provinces he visited there were statues set for him by the government expressing their loyalty.

Pausanius I, iii, 2: "There (in the Agora in Athens) stands a statue of Zeus called Eleutherios (Freedom-bringer) and also one of the Emperor Hadrian, who conferred benefits upon all those whom he ruled but especially upon the city of Athens. Pausanius also mentioned that there was another famous portrait for Hadrian within the cella of the Pathenon (I, XXXIV), another in Arcadia (VIII, XIX,1) and another in the pronaos of the temple of Zeus at Olympia.

Marcus Aurelius 161 AD- 180 AD The artistic development of his reign is not well documented except for very few things like temple dedicated to the Divine Antoninus and another one built to honour his wife Faustina after her death. There were some scattered about sculptures during his reign. He had a great respect for artists in all fields

In Meditations V, 1,2 "In their devotion to their arts, wear themselves to the bone, and immersing themselves in their tasks, go without washing or eating. But you respect your own nature less than an engraver respects his engraving"

Commodus 180 AD-192 AD The portraits of Commodus were of different style in comparison to those of the Roman Emperors. He saw himself as a gladiator, he accepted

Statues to represent him as god ex. Hercules.

Dio Cassius LXXII, 22, 3: "Commodus saw himself as a gladiator. And no one should disbelieve this. For the cut off the head of the colossus and replaced it with another which bore his own features. He also gave it a club but some kind of bronze lion beneath it so that it would resemble Hercules; then he inscribed on it, in addition to the titles by which he was usually designated, this phrase: "Champion of the seuc-tores, the only left handed gladiator to overcome a thousand"

Historia Augusta, Commodus Antoninus IX,4 "He accepted sttaues in his honour representing him with the attributes of Hercules, and offerings were made to him as the god (Politt, J.J, 1983).

\section{Conclusion}

Private Roman portrait sculptures were more associated to funerary usage rather than daily life. Most of these sculptures show the person either alone or with members of the family or court dressed in an artistic stylized fashion. Large numbers of portraits including mummy portraits have been discovered along the Roman Empire yet those discovered in Egypt were mostly unique. Although there was a direct influence from the art of the Hellenistic period, yet there were certain features and characteristics which differentiated the Egyptian portraits both imperial and private from other cultures and civilizations. This can be applied to Egyptian neighboring countries, Egypt was the source and starting point. The nearby countries added some of its influential characteristics but still under the umbrella of the Egyptian style. The description of these portraits in the works of the classical writes had always played a major role in identifying the style of the period, the kind of stone, the facial features, differences and similarities between 
these works and the other parts of the Eastern and Western Roman Empire. Art in Egypt and especially sculpture is a chain that lasted for thousands of years and the Roman period is just a part of it but an important one which helps to throw the light on the major artistic features of the period. With the rise of Christianity the ideas and themes changed, new features and characteristics yet applied by the same artist.

\section{References}

Brown, V.M \& Harell, J.A 1995, "Topographical and Petrological survey of Ancient Roman Quarries in the eastern desert of Egypt" in Maniatis, Y, Herz, N \& Basiakos, Y (eds) The Study of Marble and Other Stones used in Antiquity, Dorest, 221-231

Claridge, A 1998, "Rome, ancient, sculpture, materials" in Turner, J (ed.) The Dictionary of Art, Oxford University Press, 13-20

Gregory, A.P 1996, "Powerful Images: responses to Portraits and the Political Uses of Images in Rome", JRS, 80-90

Hannestad, N 1994, Roman Art and Imperial Policy, Aarhus University Press, 284-292

Hekleir, D 1912, Greek and Roman Portraits, New York: G. P. Putnam's Sons, XXXIII-XXXV

Janson, H.W 1971, The Story of Art, the History of Major Visual Arts from the beginning of History to the Present Day, Abrams, New York, 139-145

Kleiner, D 1992, Roman Sculpture, Yale University Press, 1-3, 6-10, 11-14, 208-210

Pensabene, P 1995, "Some problems related to the use of Luna marble in Rome and the western provinces during the first century AD", in Maniatis, Y \& Basiakos, Y (eds.) The Study of Marble and Other Stones used in Antiquity, (Archetype15-20

Perkins, J.B.W 1992 "Materials, Quarries and Transportation" in Perkins J.B.W (ed.) Marble in Antiquity, Archaeological Monographs of the British School at Rome 6, London, 13

Pollitt, J.J 1993, Art in the Hellenistic Age, Cambridge University Press, 250-252

Pollitt, J.J, 1993 "Rome: The Republic and Early Empire" in Boardman, J (ed.) The Oxford History of Classical Art, Oxford University Press, 275-282

Pollitt, J.J, 1993, The Art of Rome, Sources and Documents, Cambridge University, 11-20

Rutledge, S.H 2002, Imperial Inquisitions: Prosecutors and Informants from Tiberius to Domitian, Routledge, 30-42

Smith, R.R.R 1996, "Typology and Diversity in the Portraits of Augustus", JRS 9, 30-47

Smith, R.R.R 1988, Hellenistic Royal Portraits, Oxford University Press, 89-90

Zanker, P 1998, The Power of Images in the Age of Augustus, University of Michigan Press, $101,102,188-190$ 